\title{
Enhanced carbon acquisition and use efficiency alleviate microbial carbon relative to nitrogen limitation under soil acidification
}

Tianpeng Li ${ }^{1,2}$, Ruzhen Wang ${ }^{1}$, Jiangping Cai ${ }^{1}$, Yani Meng ${ }^{1}$, Zhirui Wang ${ }^{1,2}$, Xue Feng ${ }^{1}$, Heyong Liu ${ }^{1}$, Ronald F. Turco ${ }^{3}$ and Yong Jiang ${ }^{1 *}$

\begin{abstract}
Background: Soil microbial communities cope with an imbalanced supply of resources by adjusting their element acquisition and utilization strategies. Although soil pH has long been considered an essential driver of microbial growth and community composition, little is known about how soil acidification affects microbial acquisition and utilization of carbon $(C)$ and nitrogen $(\mathrm{N})$. To close the knowledge gap, we simulated soil acidification and created a $\mathrm{pH}$ gradient by adding eight levels of elemental sulfur (S) to the soil in a meadow steppe.

Results: We found that S-induced soil acidification strongly enhanced the ratio of fungi to bacteria (F:B) and microbial biomass $C$ to $N(M B C: M B N)$ and subsequently decreased the C:N imbalance between microbial biomass and their resources. The linear decrease in the $\mathrm{C}: \mathrm{N}$ imbalance with decreasing soil pH implied a conversion from $\mathrm{N}$ limitation to $C$ limitation. To cope with enhanced $C$ versus $N$ limitation, soil microbial communities regulated the relative production of enzymes by increasing the ratio of $\beta$-glucosidase ( $B G, C$-acquiring enzyme) to leucine aminopeptidase (LAP, N-acquiring enzyme), even though both enzymatic activities decreased with $\mathrm{S}$ addition. Structural equation modeling (SEM) suggested that higher C limitation and C:N-acquiring enzyme stimulated microbial carbon-use efficiency (CUE), which counteracted the negative effect of metal stress (i.e., aluminum and manganese) under soil acidification.
\end{abstract}

Conclusions: Overall, these results highlight the importance of stoichiometric controls in microbial adaption to soil acidification, which may help predict soil microbial responses to future acid deposition.

Keywords: Soil acidification, Stoichiometric imbalance, Metal stress, Ecoenzymatic stoichiometry, Element-use efficiency

\section{Introduction}

Ecological stoichiometry theory (EST) suggests that microbial growth and metabolism are limited by the scarcest elements when the stoichiometry of microbial resources becomes mismatched from the optimal ratios of microbial demands (Mooshammer et al. 2014a;

\footnotetext{
* Correspondence: jiangyong@iae.ac.cn

${ }^{1}$ Erguna Forest-Steppe Ecotone Ecosystem Research Station, Institute of Applied Ecology, Chinese Academy of Sciences, Shenyang 110016, China Full list of author information is available at the end of the article
}

Sterner and Elser 2002). Soil microbial communities, in turn, could cope with an imbalanced supply of resources by adjusting their element acquisition and utilization strategies (Fig. 1) (Spohn 2016). For instance, microbes secrete more $\mathrm{C}$-acquiring enzymes in soils with narrow $\mathrm{C}: \mathrm{N}$ ratios after long-term $\mathrm{N}$ enrichment (Schleuss et al. 2019), while $\mathrm{N}$-acquiring enzymatic activities are higher in extremely barren ecosystems with wide soil C:N ratios (Cui et al. 2018; Tapia-Torres et al. 2015). On the other hand, microbes can adjust element utilization via 


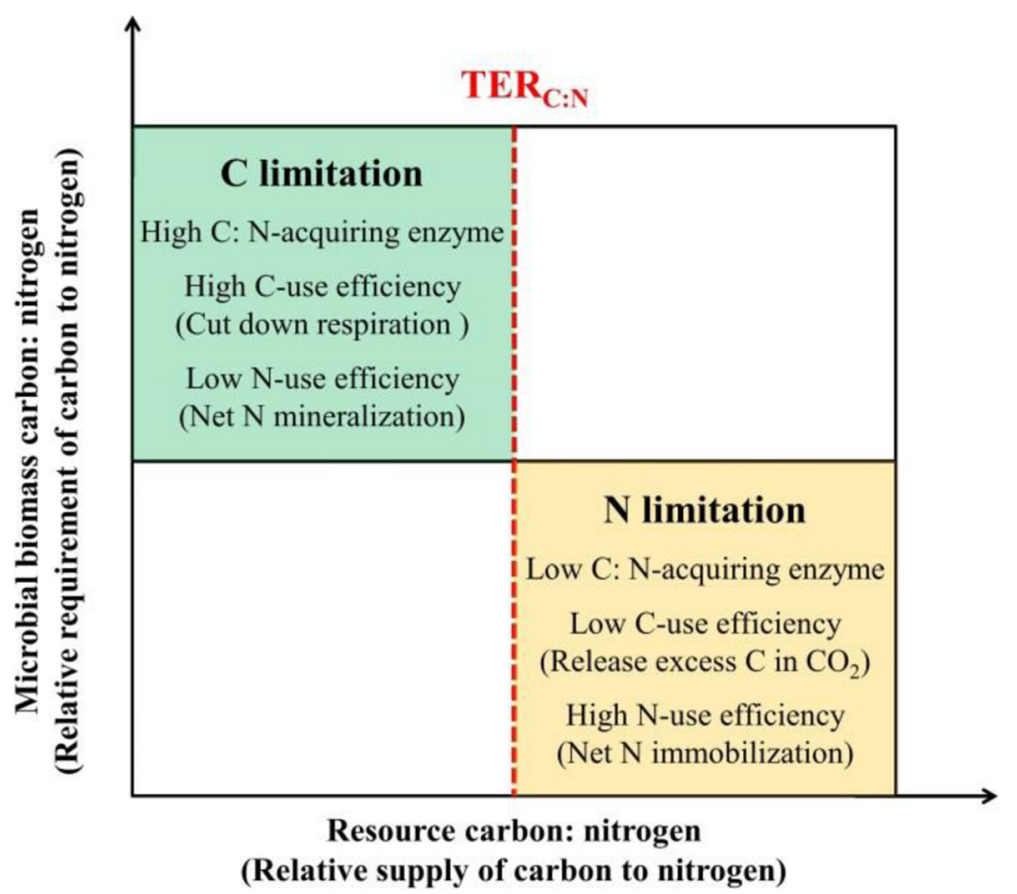

Fig. 1 Conceptual diagram illustrating relative microbial element limitation and their adaptive strategies to imbalanced supply of resources relative to requirements. Microbial communities tend to increase acquisition and use efficiency of the scarcest element to cope with imbalanced element supply and requirements. The transition from nutrient limitation to energy (C) limitation corresponds to the threshold element ratio (TER), which links EST and metabolic theory of ecology (MTE). It is important to emphasize that the TER $\mathrm{C}_{\mathrm{N} N}$ is not a constant, especially for nonhomeostatic communities, but is sub-linearly correlated with biomass C:N (Sinsabaugh et al. 2013)

regulating their physiological processes when facing resource imbalance (Spohn 2016). Net N immobilization by microbes occurs when $\mathrm{N}$ is limited (Mooshammer et al. 2014b), and excess $C$ can be released to the atmosphere by increasing microbial respiration (Manzoni et al. 2010), corresponding to a low carbon-use efficiency (CUE). Conversely, microbes mineralize and release considerable $\mathrm{N}$ into the soil rather than retaining it in biomass (i.e., lower nitrogen-use efficiency, NUE) when $\mathrm{N}$ is sufficient in their substrates (Mooshammer et al. 2014b). The threshold elemental ratio (TER) was proposed to reflect the critical ratios of substrate C:N (or $\mathrm{P})$, at which microbial growth and metabolism shifts from elemental mineralization (i.e., C:N or C:P lower than TER, $\mathrm{C}$ limitation) to immobilization (i.e., $\mathrm{C}: \mathrm{N}$ or C:P higher than TER, nutrient limitation; Fig. 1) (Frost et al. 2006). Recent studies have linked microbial adaption processes with changing element limitations induced by climate change and anthropogenic disturbance (Guo et al. 2020; Yuan et al. 2019).

Terrestrial ecosystems worldwide are facing a growing risk of soil acidification ( $\mathrm{Lu}$ et al. 2014; Schrijver et al. 2012; Yang et al. 2012) as a result of atmospheric nitrogen $(\mathrm{N})$ and sulfur $(\mathrm{S})$ deposition and inorganic fertilizer application (Bowman et al. 2008; Cui et al. 2014). Soil acidification has been shown to affect soil $\mathrm{C}$ and $\mathrm{N}$ cycling, thereby changing ecosystem functions (Poschenrieder et al. 2008; Wang et al. 2006). Soil enzyme activities are sensitive to soil acidification (Kunito et al. 2016) due to the increasing toxic effects of protons $\left(\mathrm{H}^{+}\right)$and aluminum ions $\left(\mathrm{Al}^{3+}\right)$ (Van Den Berg et al. 2005). Similarly, increasing manganese $\left(\mathrm{Mn}^{2+}\right)$ and exchangeable $\mathrm{Al}^{3+}$ contents with decreasing $\mathrm{pH}$ (Feng et al. 2019) would decrease soil CUE (Jones et al. 2019) because microbial resistance to toxic metals is energy-intensive (Bellion et al. 2006). Furthermore, given that the bacterial community is more sensitive to low $\mathrm{pH}$ and $\mathrm{Al}^{3+}$ stress than fungi (Rousk et al. 2010a), a shift towards fungal dominance is expected following soil acidification (Chen et al. 2013; Meng et al. 2019). In addition to direct detrimental effects, soil acidification increased soil $\mathrm{N}$ availability and decreased soil C:N ratios (i.e., increasing $\mathrm{N}$ supply to microorganisms) (Meng et al. 2019; Xiao et al. 2020), whereas the microbial biomass $C: N$ ratio (reflecting the relative status of microbial $\mathrm{C}$ and $\mathrm{N}$ demands according to Zechmeister-Boltenstern et al. 2015) would vary following the ratio of fungi to bacteria (Strickland and Rousk 2010). We need to examine soil acidification impacts on $\mathrm{C}$ and $\mathrm{N}$ cycling from a stoichiometric standpoint, considering the potential variations in $\mathrm{C}: \mathrm{N}$ ratios of both microbial biomass and resources under soil acidification. However, how soil 
acidification affects microbial nutrient limitation and further regulates microbial nutrient acquisition and utilization is still an open question.

A variety of $\mathrm{N}$ addition experiments showed that stoichiometric controls play a key role in alleviating microbial $\mathrm{C}$ limitation by increasing $\mathrm{C}$-acquiring enzymatic activity and CUE under $\mathrm{N}$ addition (Spohn et al. 2016; Yuan et al. 2019). However, concomitant changes in nitrogen availability and soil acidification could both contribute to the observed $\mathrm{C}$ processes in $\mathrm{N}$ addition studies, which is hard to disentangle (Yuan et al. 2019). Moreover, higher soil $\mathrm{N}$ availability tends to decrease soil fungi to bacteria (F:B) ratio due to bacterial preference of N-rich environments, while soil acidification increases it because of the higher proliferation of fungi relative to bacteria (Rousk et al. 2010a; Strickland and Rousk 2010). These conflicting responses of the F:B ratio to soil availability versus acidification would further add uncertainty to predicting microbial nutrient acquisition and utilization under $\mathrm{N}$ addition (Averill and Waring 2018). Therefore, direct evidence is needed to estimate whether stoichiometric adjustment processes help the microbial community cope with the expected higher $\mathrm{N}$ supply but lower $\mathrm{N}$ requirements under soil acidification without exogenous $\mathrm{N}$ input.

Over the last two decades, temperate semi-arid grassland, one of China's most important ecosystems, has experienced elevated soil acidification from atmospheric acid deposition (Yang et al. 2012). Our objectives were to investigate how S-induced soil acidification affects microbial nutrient limitation, acquisition, and utilization strategies, as revealed by enzymatic stoichiometry and element-use efficiency. We conducted an acidification gradient experiment by applying eight elemental S levels to the soil in a meadow steppe. We investigated soil acidification impacts on enzyme activities and the coupled relationships of microbial C:N ratios with their bioavailable resources. We hypothesized that (1) Sinduced soil acidification could alleviate microbial $\mathrm{N}$ vs. $\mathrm{C}$ limitation by increasing $\mathrm{N}$ supply but reducing microbial $\mathrm{N}$ requirements by increasing the ratio of $\mathrm{F}: \mathrm{B}$; (2) to cope with decreasing $\mathrm{N}$ limitation but increasing $\mathrm{C}$ limitation, the microbial community would increase $\mathrm{C}: \mathrm{N}$-acquiring enzymatic ratios; and (3) increasing microbial CUE due to higher $C$ requirements may counteract the negative effects of enhanced metal stress on CUE under soil acidification.

\section{Materials and methods}

\section{Site description}

This experiment was conducted in a semi-arid meadow fenced since 2013 at the Erguna Forest-Steppe Ecotone Research Station in Inner Mongolia, China $\left(50^{\circ} 10^{\prime} \mathrm{N}\right.$, $119^{\circ} 23^{\prime} \mathrm{E}, 650 \mathrm{~m}$ a.s.l.). The long-term mean annual air temperature of this site is $-2.5^{\circ} \mathrm{C}$, and the mean annual precipitation is $374 \mathrm{~mm}$ (according to the data from 1957 to 2016). The meadow grassland in this study is dominated by Leymus chinensis, Stipa baicalensis, Carex duriuscula, and Pulsatilla chinensis. The soil is classified as chernozem (FAO) with a composition of 39\% sand, $37 \%$ silt, and $24 \%$ clay. The soil bulk density is $1.21 \mathrm{~g}$ $\mathrm{cm}^{-3}$, and the average soil $\mathrm{pH}(0-10 \mathrm{~cm})$ is 6.8 . No fertilizer was added before this experiment, and natural $\mathrm{S}$ deposition is lower than $0.4 \mathrm{~g} \mathrm{~S} \mathrm{~m}^{-2}$ year $^{-1}$ in this grassland (Ge et al. 2014).

\section{Experimental design and soil sampling}

The $\mathrm{S}$ addition experiment was arranged in a randomized block design that was established in early 2017 . Eight rates of S addition (0, 1, 2, 5, 10, 15, 20, and $50 \mathrm{~g} \mathrm{~S}$ $\mathrm{m}^{-2}$ year $^{-1}$ ) were assigned in each of five replicate blocks. Each block consisted of eight plots of size $6 \times 6$ $\mathrm{m}$ and a 2-m buffer zone between adjacent plots. Lower $\mathrm{S}$ addition rates (i.e., 1 and $2 \mathrm{~g} \mathrm{~S} \mathrm{~m}^{-2}$ year $^{-1}$ ) simulated increasing natural acid deposition in recent decades $(\mathrm{Yu}$ et al. 2017), and the higher rates mimicked aggravating soil acidification induced by accumulative acid deposition in the long term. Elemental S (>99.9\% purity), which has been widely used to modify soil $\mathrm{pH}$ in farmlands (Bole 1986) and grasslands (Owen et al. 1999), was added evenly in the form of powder on May 20th each year since 2017. Soil samples were collected in August 2018 (i.e., 3 months after the second-year S addition), where five cores of topsoil $(0-10 \mathrm{~cm})$ were taken randomly and then mixed thoroughly for each plot. The homogenized soil samples were passed through a $2-\mathrm{mm}$ sieve to remove rocks and plant residuals immediately; the sieved soil samples were transferred to the laboratory within $2 \mathrm{~h}$ and divided into three subsamples. Subsamples for measuring microbial biomass, enzyme activities, and inorganic nitrogen were stored at $4{ }^{\circ} \mathrm{C}$ before analysis, and subsamples for determining PLFAs were held at $-20^{\circ} \mathrm{C}$. The remaining soil samples were air-dried at room temperature and used for the determination of the soil abiotic characteristics.

\section{Measurement of soil biochemical properties Soil abiotic characteristics}

Soil $\mathrm{pH}$ was measured in a soil slurry using a soil to water ratio of $1: 5(\mathrm{w} / \mathrm{v})$ by a $\mathrm{pH}$ meter (Precision and Scientific Corp., Shanghai, China). Soil dissolved carbon (DOC) and total dissolved nitrogen (TDN) concentrations were extracted from $10 \mathrm{~g}$ of fresh soil with $40 \mathrm{~mL}$ of $0.5 \mathrm{M} \mathrm{K}_{2} \mathrm{SO}_{4}$ solution and determined using a TOC analyzer (HT1300, Analytikjena, Jena, Germany). Other soil abiotic characteristics, including soil organic carbon (SOC), total nitrogen (TN), exchangeable $\mathrm{Al}^{3+}$, and 
available $\mathrm{Mn}^{2+}$, were determined using air-dried soil as described in detail in Methods S1.

\section{Soil microbial biomass}

Soil microbial biomass carbon $(\mathrm{MBC})$ and nitrogen $(\mathrm{MBN})$ were measured using the chloroform $\left(\mathrm{CHCl}_{3}\right)$ fumigation-extraction method within 7 days of sampling (Vance et al. 1987). Microbial biomass was calculated as $E / k$, where $E=$ (dissolved element extracted from a fumigated soil sample) - (dissolved element extracted from a non-fumigated soil sample) and conversion factor $k$ was 0.45 and 0.54 for MBC (Joergensen 1996) and MBN (Brookes et al. 1985), respectively.

\section{Soil enzyme activities}

Enzyme measurements for $\beta$-glucosidase (BG), $\beta-N$ acetyl-glucosaminidase (NAG), and leucine aminopeptidase (LAP) were performed on fresh soil samples within 14 days after sampling with a colorimetric method using $\rho$-nitrophenyl- $\beta$-D-glucopyranoside, $\rho$-nitrophenyl-Nacetyl- $\beta$-D-glucosaminide and leucine $\rho$-nitroanilide (Sigma, St. Louis, USA) as the substrate under the opti$\mathrm{mal} \mathrm{pH}$, temperature and substrate concentrations (Robertson et al. 1999; Sinsabaugh et al. 1999; Tabatabai 1994) (a detailed description is provided in Methods S1). Enzyme activities were expressed as $\mu \mathrm{mol} \rho \mathrm{NP}$ per gram soil per hour, and specific enzyme activities were calculated as mmol $\rho N P$ per gram MBC per hour.

\section{Microbial community composition}

The microbial community composition of the soil samples was determined using the phospholipid fatty acids (PLFAs) method. The PLFAs were extracted from frozen soil samples and then separated and methylated (Bossio and Scow 1998) before analysis. The methylated PLFAs were then analyzed with an Agilent 7890A gas chromatograph (Agilent Technologies, Palo Alto, California, USA) and identified with a MIDI Sherlock Microbial Identification System (MIDI Inc., Newark, DE, USA). The sum of the following PLFAs represents bacteria: i14:

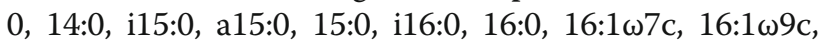

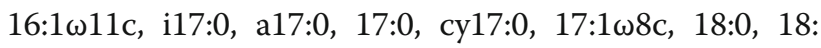
$1 \omega 5 \mathrm{c}, 18: 1 \omega 7 \mathrm{c}, 18: 1 \omega 9 \mathrm{c}, 18: 1 \omega 8 \mathrm{t}$, and cy19:0 (Bååth and Anderson 2003; Frostegård and Bååth 1996), and general

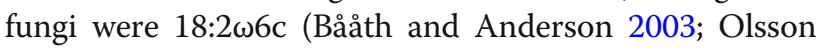
et al. 1995). Here, we calculated the ratio of fungi to bacteria (F:B) using the concentrations of general fungi relative to the sum of bacterial PLFAs. We calculated microbial stress biomarkers using the ratio of saturated FAs $(16: 1 \omega 5 \mathrm{c}, 17: 1 \omega 8 \mathrm{c}$, and $18: 1 \omega 7 \mathrm{c})$ to monounsaturated FAs (14:00, 15:00, 16:00, 17:00 and 18:00) (sat: mono) and cyclopropyl FAs (cy17:0 + cy19:0) to their monoenoic precursor $(16: 1 \omega 7 \mathrm{c}+18: 1 \omega 7 \mathrm{c})$ (cy:pre) (Kaur et al. 2005; Siles et al. 2015).

\section{Calculations}

Stoichiometric imbalance

We calculated the stoichiometric imbalance between microbes and their resources (i.e., total dissolved forms of $\mathrm{C}$ and $\mathrm{N}$ ) by dividing stoichiometric ratios of resources by stoichiometric ratios of microbial biomass (Mooshammer et al. 2014a). We used DOC and TDN as resources for microorganisms rather than total organic elements because these labile forms were considered to be more accessible for microbes and thus better indicators of microbial resources (Mooshammer et al. 2014a; Zhang et al. 2019). Additionally, we also calculated the stoichiometric imbalance using SOC:TN as a resource stoichiometric ratio to compare with the labile forms.

\section{Ecoenzymatic stoichiometry}

Enzymatic stoichiometry was calculated as the ratio of nutrient-acquiring enzyme activity (i.e., BG as Cacquiring enzyme and NAG + LAP as N-acquiring enzyme). A type II standard major axis (SMA) regression analysis was conducted to detect the relationships between $\log _{\mathrm{e}}$-transformed enzymes (in nmol $\rho \mathrm{NP} \mathrm{g}^{-1}$ soil $\mathrm{h}^{-1}$ ) with the smatr package in $\mathrm{R}$ (Warton et al. 2012).

\section{Threshold element ratios (TER)}

We calculated the TER for C:N to understand the tradeoff between energy (i.e., carbon) and nitrogen controls of microbial communities in response to soil acidification, which connects the EST with the Metabolic Theory of Ecology (MTE) using the following equations (Sinsabaugh et al. 2009):

$\mathrm{TER}_{\mathrm{C}: \mathrm{N}}=\left(\mathrm{E}_{\mathrm{C:N}} \times \mathrm{B}_{\mathrm{C}: \mathrm{N}}\right) / n_{0}(1)$

where $\mathrm{TER}_{\mathrm{C}: \mathrm{N}}$ is the threshold element ratio (dimensionless) for $\mathrm{C}: \mathrm{N} ; \mathrm{E}_{\mathrm{C}: \mathrm{N}}$ represents the ratio of $\mathrm{C}$ acquiring enzyme (BG) to N-acquiring enzymes (NAG + $\mathrm{LAP}) ; \mathrm{B}_{\mathrm{C}: \mathrm{N}}$ represents the $\mathrm{C}: \mathrm{N}$ ratio of soil microbial biomass; and $n_{0}$ is a dimensionless constant calculated by raising e to the intercept of the SMA regression relationship between $\log _{e}(B G)$ and $\log _{e}(N A G+$ LAP). We compared the estimated TER $\mathrm{C}_{\mathrm{N}}$ with DOC:DON, with a higher TER indicating that microbial growth was limited by energy (net nitrogen mineralization), while a lower TER represented $\mathrm{N}$ limitation (net $\mathrm{N}$ immobilization) (Sinsabaugh et al. 2013).

\section{Carbon and nitrogen use efficiency}

We calculated the CUE and NUE based on the C:N stoichiometry of soil resources, microbial mass and enzymes (Sinsabaugh et al. 2016) using equations (2), (3), (4), and (5):

$$
\begin{aligned}
& \mathrm{CUE}=\mathrm{CUE}_{\max }\left[\mathrm{S}_{\mathrm{C}: \mathrm{N}} /\left(\mathrm{S}_{\mathrm{C}: \mathrm{N}}+K\right)\right](2) \\
& \mathrm{S}_{\mathrm{C}: \mathrm{N}}=\left(1 / \mathrm{E}_{\mathrm{C}: \mathrm{N}}\right)\left(\mathrm{B}_{\mathrm{C}: \mathrm{N}} / \mathrm{L}_{\mathrm{C}: \mathrm{N}}\right)(3) \\
& \mathrm{NUE}=\mathrm{NUE}_{\max }\left[\mathrm{S}_{\mathrm{N}: \mathrm{C}} /\left(\mathrm{S}_{\mathrm{N}: \mathrm{C}}+K\right)\right](4) \\
& \mathrm{S}_{\mathrm{N}: \mathrm{C}}=\left(1-1 / \mathrm{E}_{\mathrm{C}: \mathrm{N}}\right)\left(\mathrm{L}_{\mathrm{C}: \mathrm{N}} / \mathrm{B}_{\mathrm{C}: \mathrm{N}}\right)(5)
\end{aligned}
$$


where $\mathrm{CUE}_{\max }$ is 0.6 and represents the upper limit for microbial growth efficiency based on thermodynamic constraints (Roels 1980; Sinsabaugh et al. 2013) and NUE ${ }_{\max }$ is fixed to 1.0 (Sinsabaugh et al. 2016); $\mathrm{S}_{\mathrm{C}: \mathrm{N}}$ represents the extent to which enzymatic allocations offset the differences between the elemental composition of soil resources and microbial biomass; $K$ is the half-saturation constant (0.5); $\mathrm{L}_{\mathrm{C}: \mathrm{N}}$ represents the $\mathrm{C}: \mathrm{N}$ ratio of soil labile resources (i.e., DOC: TDN) (Sinsabaugh et al. 2016). The estimated microbial CUE and NUE were proven to be effective in predicting nutrient requirements and use efficiency (Geyer et al. 2019) and closely matched the physiological metabolism process, such as microbial respiration (Yuan et al. 2019) and ammonification rate (Zechmeister-Boltenstern et al. 2015). The reliability of estimated CUE to predict microbial carbon utilization was further proven by the negative correlation between estimated CUE and microbial metabolic quotient in our study (Appendix 3 in the Supporting Information).

\section{Statistical analysis}

The Kolmogorov-Smirnov test and Levene's test were performed to ensure the normality of data and homogeneity of variances. We used a linear mixed-effects model to test the effects of S on soil biochemistry indices, enzyme activity, and stoichiometry. S addition rates were designated as fixed effects with blocks as random effects. Duncan's multiple range test was conducted to detect the differences between each $\mathrm{S}$ addition rate $(P$ $<0.05)$. We used a linear regression analysis to test the correlation between variables and decreasing soil $\mathrm{pH}$.

We conducted a structural equation modeling (SEM) analysis in this study to examine the direct and indirect strength of soil acidification on microbial nutrient cycling. In this analysis, we assumed that a decrease in soil $\mathrm{pH}$ may first alter the stoichiometry of microbial biomass and its resources and toxic metal ions, thus affecting stoichiometric imbalance and microbial stress and further causing changes in enzyme stoichiometry and nutrient use efficiency (Table S1 and Fig. S1). Principal component analysis (PCA) was conducted to simplify our models using the extracted PC1 values of toxic metal concentrations (i.e., $\mathrm{Al}^{3+}$ and $\mathrm{Mn}^{2+}$ ) and microbial stress biomarkers (including sat:mono and cy:pre), respectively (Fig. S2). The piecewise SEMs were finally established with Amos 24.0 (Amos Development Co., Greene, Maine, USA) using the maximum likelihood estimation method. The $\chi^{2}$ test $(P>$ 0.05 ), root square mean errors of approximation (RMSEA $<0.08$ ), and Akaike information criteria (AIC) were used to evaluate the adequacy of the model.

\section{Results}

Responses of soil abiotic properties to $\mathrm{S}$ addition

Soil $\mathrm{pH}$ showed a significant decrease from 6.87 to 5.99 with the increasing rate of $\mathrm{S}$ addition $(P<0.01$, Fig. 2$)$, while the exchangeable $\mathrm{H}^{+}$and $\mathrm{Al}^{3+}$ increased by up to $82.62 \%$ and $52.71 \%$, respectively $(P<0.01$, Table S2). In addition, soil available $\mathrm{Mn}^{2+}$ concentrations increased significantly along the $\mathrm{S}$ addition gradient (Table S2). Sulfur addition increased the ratio of SOC:TN from 11.86 to $12.32(P=0.04$, Fig. S3). Soil DOC and TDN increased $(P$ $<0.01$, Table S2) along the $\mathrm{S}$ addition gradient. We observed a significantly lower DOC:TDN in the $\mathrm{S}$ addition treatments than in the control plots, which was positively correlated with soil $\mathrm{pH}\left(R^{2}=0.15, P=0.03\right.$, Fig. $\left.2 \mathrm{~b}\right)$. Sulfur addition significantly decreased the $\mathrm{NO}_{3}{ }^{-} \mathrm{N}$ concentration but increased DON $(P<0.01$, Table S2).

\section{Responses of microbial biomass, stoichiometric} imbalance, and community structure to $\mathrm{S}$ addition Sulfur addition decreased both soil MBC and MBN (Table S2) but increased MBC:MBN along with decreasing soil $\mathrm{pH}\left(R^{2}=0.39, P<0.01\right.$, Fig. $\left.2 \mathrm{c}\right)$, resulting in a dramatic decline in the $C: \mathrm{N}$ imbalance from 0.42 to 0.24 $\left(R^{2}=0.29, P<0.01\right.$, Fig. $\left.2 \mathrm{~d}\right)$. Sulfur addition significantly decreased the total PLFAs $\left(R^{2}=0.13, P=0.03\right.$, Fig. 3a) but increased the relative abundance of fungi $\left(R^{2}=0.43\right.$, $P<0.01$, Fig. 3c). However, the relative abundance of bacteria was the lowest at the highest level of $\mathrm{S}$ addition (Fig. 3b), causing a significant increase in the ratio of fungi to bacteria (F:B) with soil acidification. With respect to soil microbial stress indicators, $\mathrm{S}$ addition increased the ratios of saturated-to-monounsaturated PLFAs (sat:mono) and cyclopropyl FA-to-monoenoic precursor (cy:pre), with both ratios negatively relating to soil $\mathrm{pH}(P<0.01$, Fig. 3e, $\mathrm{f}$ and Fig. S2b).

\section{Responses of ecoenzymatic stoichiometry and threshold element ratio to $\mathrm{S}$ addition}

Soil BG and LAP activity decreased with S-induced acidification $(P<0.01$, Fig. $4 \mathrm{a}, \mathrm{c})$. The NAG activity $(P=$ 0.19, Fig. 4b) and BG: (NAG + LAP) ratio showed no response to $\mathrm{S}$ addition (Fig. $4 \mathrm{~d}$ ), while the BG:LAP ratio increased significantly with increasing $S$ addition rate and decreasing soil pH (Fig. 4e). The significant correlation was observed between the BG:LAP ratio and the $C$ : $\mathrm{N}$ imbalance (Fig. 4f). Specific NAG activity (per unit of $\mathrm{MBC}$ ) increased with decreasing $\mathrm{pH}$ (Fig. S4). The type II regression showed that $\mathrm{C}$ - and $\mathrm{N}$-acquiring enzyme activities were positively correlated $\left(R^{2}=0.65, P<0.01\right.$, Fig. S5). The TER increased with decreasing soil $\mathrm{pH}$ under $\mathrm{S}$ addition $\left(R^{2}=0.18, P<0.01\right.$, Fig. $\left.5 \mathrm{a}\right)$.

\section{Responses of microbial nutrient-use efficiency to $S$ addition and linkages with the stoichiometric imbalance and community structure}

Compared with the control plot, high rates of S addition significantly increased CUE (Fig. 5b) but decreased NUE (Fig. 5c). Significant correlations were observed between 


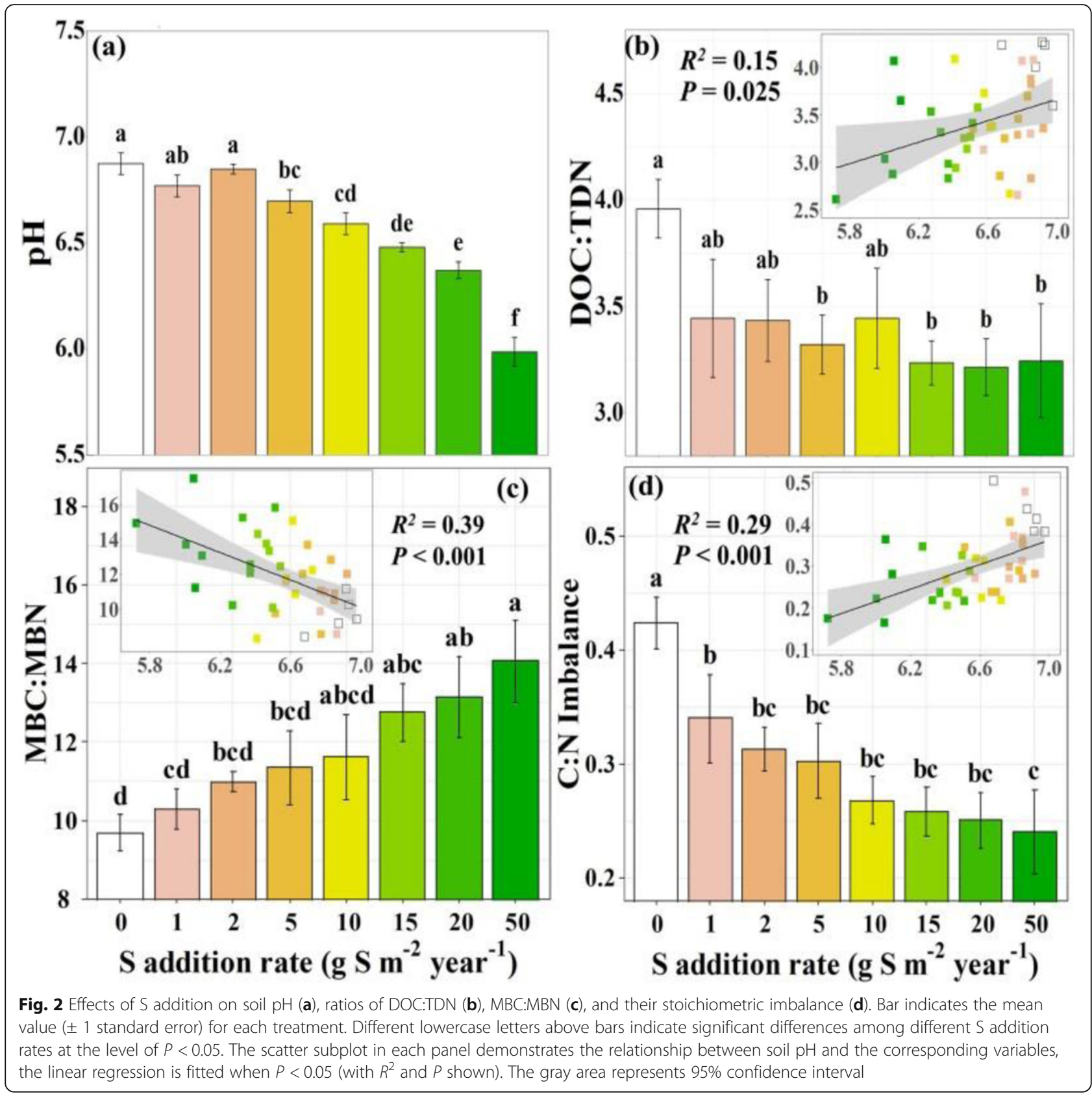

soil $\mathrm{pH}$ and CUE (negative, $R^{2}=0.24, P<0.01$, Fig. $5 \mathrm{~b}$ ), and between soil $\mathrm{pH}$ and NUE (positive, $R^{2}=$ $0.25, P<0.01$, Fig. 5c).

Our final SEMs fit the data well $\left(\chi^{2}{ }_{\text {CUE }}=30.54\right.$, $P_{\mathrm{CUE}}=0.082$ and $\chi_{\mathrm{NUE}}^{2}=31.42, P_{\mathrm{NUE}}=0.088$, respectively) and explained $54 \%$ and $51 \%$ of the total variance in CUE and NUE, respectively (Fig. 6a, c). The piecewise SEM analyses showed that soil acidification (i.e., decreasing $\mathrm{pH}$ ) under $\mathrm{S}$ addition increased CUE but decreased NUE by enhancing the F:B ratio and BG:LAP ratio and reducing the $\mathrm{C}: \mathrm{N}$ imbalance (Fig. 6b, d). Additionally, soil acidification also indirectly decreased NUE by increasing toxic metal concentrations and microbial stress (total standard effect size $=-0.16$ and -0.21 , respectively, Fig. $6 c$ ).

\section{Discussion}

Sulfur-induced soil acidification enhanced microbial C relative to $\mathbf{N}$ limitation

Consistent with our first hypothesis, soil acidification alleviated $\mathrm{N}$ limitation but aggravated $\mathrm{C}$ limitation for the microbial community, as indicated by the increase in TER but the decrease in the C:N imbalance between microbial biomass and dissolved nutrients (Fig. 2d). The 

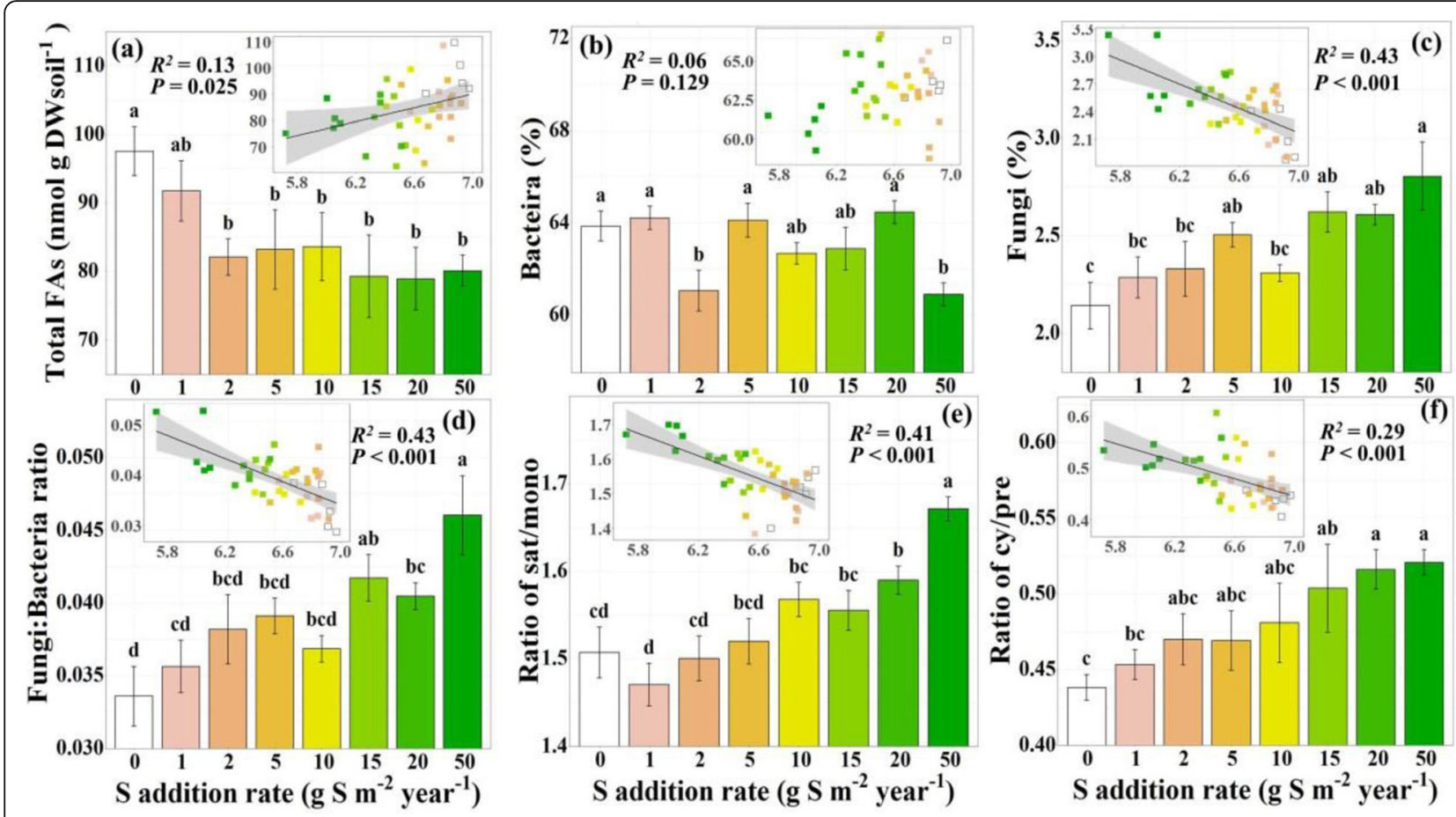

Fig. 3 Effects of S addition on total PLFAs (a), relative abundance of bacteria (b), and fungi (c) groups, ratio of fungi to bacteria (F:B, d), saturatedto-monounsaturated FAs (sat:mono, e), and cyclopropyl FAs-to-monoenoic precursor (cy:pre, f). Bar indicates the mean value ( \pm 1 standard error) for each treatment. Different lowercase letters above bars indicate significant differences among different $\mathrm{S}$ addition rates at the level of $P<0.05$. The scatter subplot in each panel demonstrates the relationship between soil $\mathrm{pH}$ and corresponding variables, the linear regression is fitted when $P<0.05$ (with $R^{2}$ and $P$ shown). The gray area represents $95 \%$ confidence interval

TER is a useful indicator for predicting microbial nutrient limitation compared with resource stoichiometry (Frost et al. 2006) and nitrogen limitation occurs when the C:N ratio is greater than the TER (Sinsabaugh et al. 2013). In this study, DOC:TDN was greater than the TER under high soil $\mathrm{pH}$ (i.e., higher than 6.6) but lower than the TER when the $\mathrm{pH}$ was lower than 6.6 (Fig. $2 \mathrm{~b}$ and $5 \mathrm{a}$ ), suggesting a conversion from $\mathrm{N}$ limitation to $\mathrm{C}$ limitation with soil acidification.

One crucial explanation for alleviating $\mathrm{N}$ limitation was the increasing $\mathrm{N}$ supply for the microbial community (Table S2) through inhibiting $\mathrm{N}$ leaching loss (Kemmitt et al. 2005; Van Den Berg et al. 2005) and plant N uptake (Vanguelova et al. 2007) under soil acidification. Additionally, increasing $\mathrm{C}$ vs. $\mathrm{N}$ limitation was potentially from the lower root exudation, one of the most critical microbial $\mathrm{C}$ resources, under soil acidification (Treseder 2008). However, the converse trends of DOC: TDN with SOC:TN in our study corroborated previous studies showing the differential responses of labile and total soil nutrient stoichiometry to changing soil $\mathrm{pH}$ (Guo et al. 2020; Yuan et al. 2019). Despite similar trends between the $\mathrm{C}: \mathrm{N}$ imbalance calculated from DOC:TDN and SOC:TN, only dissolved nutrients contributed to the variation in stoichiometric imbalance
(Fig. 6 and Fig. S3c). These results suggested that dissolved nutrient stoichiometry could be a better indicator for nutrient limitation, also reported in regional-scale studies (Wild et al. 2015), field manipulation experiments (Guo et al. 2020; Yuan et al. 2019), and modeling studies (Kaiser et al. 2014).

Another mechanism of increasing microbial $\mathrm{C}$ limitation was the relatively higher $\mathrm{C}$ requirement, as evidenced by the higher MBC:MBN ratio (Zechmeister-Boltenstern et al. 2015) under elemental $S$ addition (Fig. 2), which was primarily attributed to the higher F:B ratio (Fig. 3). Bacteria have a relatively narrow $\mathrm{pH}$ range for growth and are vulnerable to soil acidification (Fig. S6a), whereas fungi tend to be more tolerant (Fig. S6b) (Rousk et al. 2010a; Rousk et al. 2009). Moreover, fungi have a higher biomass ratio of C:N than bacteria (Strickland and Rousk 2010), contributing to an increased $\mathrm{C}: \mathrm{N}$ ratio and $\mathrm{C}$ requirement of the microbial community under soil acidification (Fig. 6a). Our results suggested that acidification-induced changes in soil microbial community structure played a considerable role in regulating biomass stoichiometry.

Decreasing $\mathrm{N}$ limitation and increasing $\mathrm{C}$ limitation were also found in $\mathrm{N}$-addition experiments (Schleuss et al. 2019; Yuan et al. 2019), accompanied by soil acidification. This shift in $\mathrm{C}$ and $\mathrm{N}$ limitations with $\mathrm{N}$ 


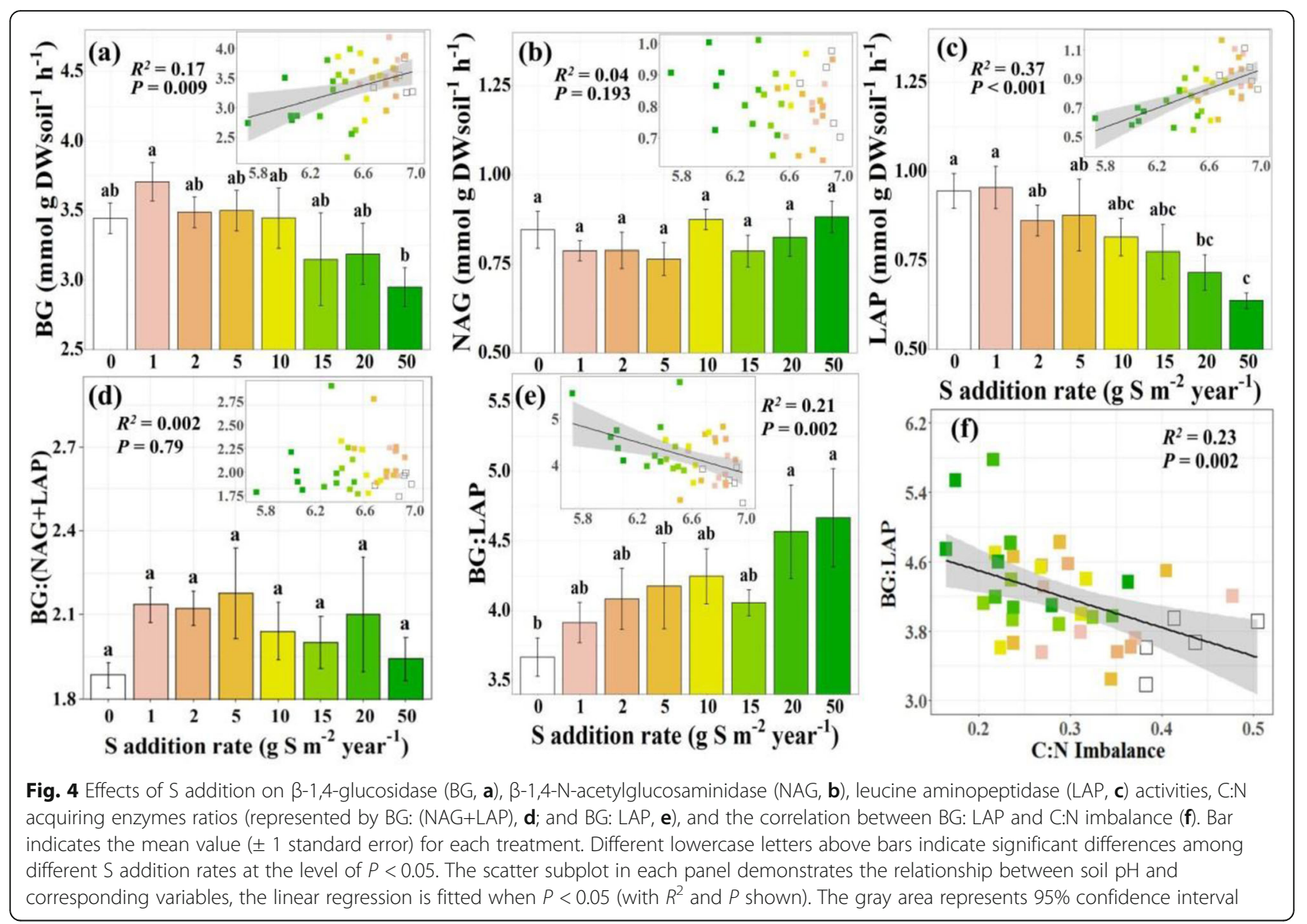

addition was attributed to changes in soil resource stoichiometry (i.e., higher $\mathrm{N}$ input with $\mathrm{N}$ addition rates) (Yuan et al. 2019). However, being different from Naddition studies, variations in stoichiometric imbalance (i.e., increasing $\mathrm{C}$ to $\mathrm{N}$ limitation here) were better explained by microbial biomass stoichiometry (i.e., nutrient demand, standard effect size $=-0.76$ ) rather than resource stoichiometry (i.e., nutrient supply, standard effect size $=0.41$ ) under S-induced soil acidification (Fig. 6). This calls for future $\mathrm{N}$-addition studies to combine

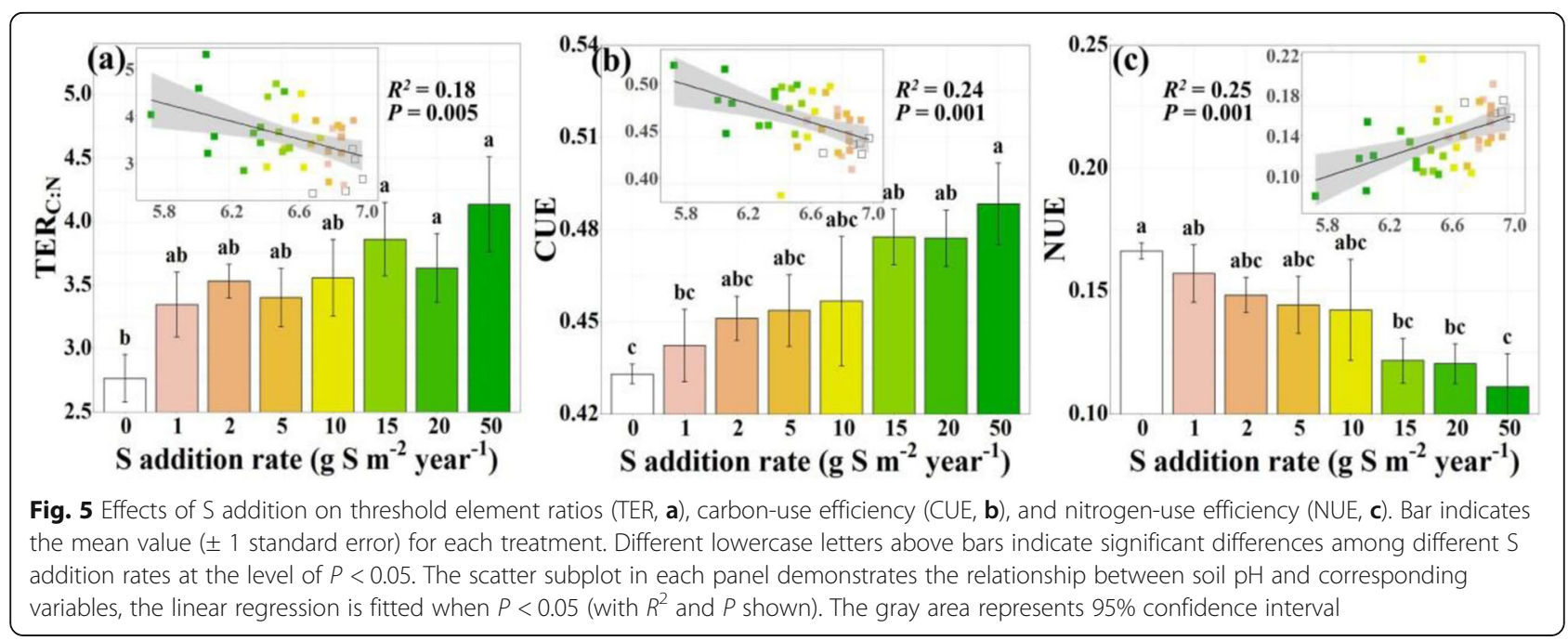




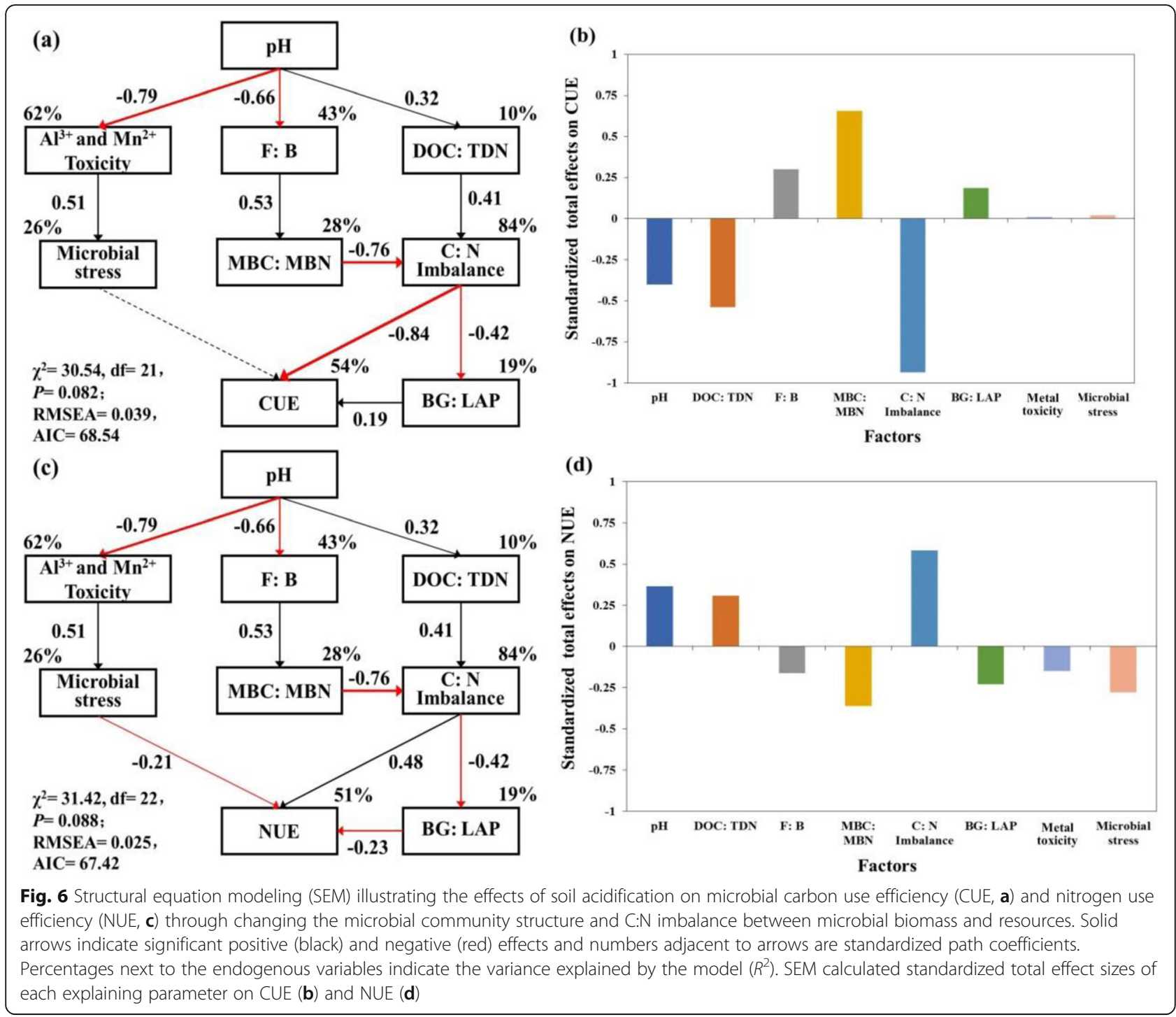

acid and nutrient additions when evaluating the effects of soil acidification on microbial nutrient limitation (Averill and Waring 2018). Moreover, regarding the high turnover of dissolved nutrients and microbial biomass as affected by soil microclimate and plant growth (Bardgett et al., 2005), multiple samplings over the growing season are still needed.

\section{Microbial community increased soil $\mathrm{C}$ - to $\mathrm{N}$-acquiring enzyme ratio to cope with higher $\mathrm{C}$ limitation under soil acidification}

Soil microorganisms secrete extracellular enzymes to acquire limited elements from organic matters (Waring et al. 2013). Although a substantial part of extracellular enzymes are stabilized in the soil matrix (Allison 2006) and lack association with active cells (Nannipieri et al. 2018), they can still reflect the catalytic history of a soil as continuously imprinted by soil microorganisms in response to environmental changes (Dilly and Nannipieri 2001). Therefore, changes in enzymatic activities and stoichiometry are widely regarded as effective indicators of microbial nutrient status in long-term observations (Schleuss et al. 2019; Tapia-Torres et al. 2015; Yuan et al. 2019). Our results showed alteration of enzymatic activities to adapt to decreasing C:N imbalance (Fig. 4f), which partially supported our second hypothesis. Adjusting elemental acquisition through regulating enzyme activities is one of the most important strategies for microbial communities to maintain elemental balances and activities in terrestrial ecosystems (Sterner and Elser 2002; Waring et al. 2013), especially in nutrient-limited areas (Tapia-Torres et al. 2015). Here, we found that specific BG activity (per unit $\mathrm{MBC}$ ) remained unchanged, while specific LAP decreased with soil acidification (Fig. S4), indicating that the microbial community tended to invest less energy in producing $\mathrm{N}$-acquiring 
enzymes relative to $\mathrm{C}$-acquiring enzymes to cope with increasing $\mathrm{C}$ to $\mathrm{N}$ limitation. However, specific NAG activity (per unit $\mathrm{MBC}$ ) increased with soil acidification (Fig. S4), which could be attributed to several mechanisms: (i) NAG is also regarded as a $\mathrm{C}$-acquiring enzyme when $\mathrm{N}$ is sufficient and usually increases with $\mathrm{N}$ addition in temperate grasslands (Schleuss et al. 2019; Wang et al. 2015) because NAG (i.e., chitinase) is responsive for hydrolyzing chitin (i.e., N-containing polysaccharide) (Sámi László et al. 2001). (ii) NAG production is expected to increase with higher fungal abundance (Fig. 3) concurrent with higher chitin production from fungal necromass (i.e., more substrate for NAG) under soil acidification. Similarly, experimentally manipulating microbial communities to decrease F:B ratio substantially reduces NAG activity even in the absence of changes in $\mathrm{pH}$ (Domeignoz-Horta et al. 2020). Therefore, we should be more cautious when treating NAG activity simply as an $\mathrm{N}$-acquiring enzyme, especially in areas where chitin could be an essential C source (Mori 2020). Instead, we found that the BG:LAP ratio could better predict microbial $\mathrm{C} v s$. $\mathrm{N}$ limitation, as suggested by the significant correlation between the BG: LAP ratio and the C:N imbalance (Fig. 4f). One possible reason is that bacteria depend more on proteins as a source of $\mathrm{N}$ (Hofmockel et al. 2010). The $\mathrm{N}$-acquisition strategy of our bacteria-dominated community was largely correlated with LAP consequently. Our result was also supported by the resource allocation theory that microbial communities might increase enzyme production to mine the scarcest elements (Allison and Vitousek 2005). Moreover, here we used optimal pHs for enzymes to determine maximum potential activities (Tabatabai et al. 1994) and allow comparison with other studies (Nannipieri et al. 2018), but the pH optimum for some extracellular enzymes may shift under long-term $\mathrm{pH}$ manipulation due to changes in functional microbial communities (Puissant et al. 2019). Therefore, the role of changing $\mathrm{pH}$ in enzyme assay should be considered in further researches. Overall, our results showed that the microbial community could alter enzyme production to adapt to increasing $\mathrm{C}$ limitation induced by soil acidification.

\section{Microbial community increased soil CUE but reduced NUE to cope with higher $\mathrm{C}$ limitation under soil acidification}

Based on EST, microbial communities tend to regulate their element utilization strategies by adjusting the physiological process of element-use efficiencies to adapt to element-limiting environments (Mooshammer et al. 2014a; Sterner and Elser 2002). Consistent with our expectation, the $\mathrm{C}: \mathrm{N}$ imbalance between microbial biomass and their resources was a key factor contributing to CUE and NUE variations under soil acidification (Figs. 6,
S7). The negative correlation between the $\mathrm{C}: \mathrm{N}$ imbalance and CUE suggested that alleviated $\mathrm{N}$ limitation allowed the microbial community to allocate more $\mathrm{C}$ to building biomass rather than providing energy for $\mathrm{N}$ acquisition with soil acidification. This was in line with Spohn et al. (2016) who observed an increase in the CUE of microbial communities with increasing $\mathrm{N}$ supply for microbes. Analogously, the microbial community releases more ammonium (i.e., low NUE) when decomposing substrates with a high $\mathrm{C}: \mathrm{N}$ ratio (Mooshammer et al. 2014b), suggesting that the changes in microbial N utilization largely depend on $\mathrm{N}$ in their resources (Keiblinger et al. 2010). Here, we also found a potential shift from net $\mathrm{N}$ immobilization to mineralization, as suggested by increasing TER with soil acidification, which was supported by $\mathrm{Li}$ et al. (2020), who found that $\mathrm{N}$ mineralization increased with decreasing soil $\mathrm{pH}$. The increasing $\mathrm{F}: \mathrm{B}$ ratio showed a positive effect on microbial CUE but negatively affected NUE (Fig. S7) because fungal communities usually have higher $\mathrm{C}$ requirements and CUE than bacterial communities (Riggs and Hobbie 2016). Additionally, both CUE and NUE showed significant correlations with BG:LAP, as we expected, supporting the principle of "return on investment" (Schimel and Weintraub 2003) that microbes invest more $C$ in producing $\mathrm{C}$-acquiring enzymes than $\mathrm{N}$-acquiring enzymes (i.e., higher BG:LAP; Fig. 4e) to mineralize more $C$ from substrates and increase the flow of $\mathrm{C}$ back to the microbes (i.e., higher CUE) to cope with increasing $\mathrm{C}$ limitation.

Our results clearly showed that microbes with high $\mathrm{S}$ addition rates were facing higher stresses, as suggested by PLFA stress indicators (i.e., ratios of sat:mono and cy: pre, Fig. 3d, e). Higher sat:mono and cy:pre ratios reflect lower fluidity of the cell membrane (Los and Murata 2004) and stationary growth phase of microbes (Bossio and Scow 1998), respectively, both of which were proven to be efficient in predicting acidity and metal stresses (Åkerblom et al. 2007; Garcia-Sanchez et al. 2015; Rousk et al. 2010b). Decreased microbial CUE and NUE might result from microbes overcoming metal stress through the $\mathrm{C}$ - and $\mathrm{N}$-costly pathways of cation efflux pumps, reactive oxygen scavenging, secretion of detoxifying compounds and elevating genes for metal resistance (Auger et al. 2013; Malik et al. 2017; Silver et al. 1989). However, the $13 \%$ increase in CUE with soil acidification in our study suggested that the negative effect of microbial stress was offset by the pathway of stoichiometric controls on microbial CUE (Fig. 6a). The different responses of microbial CUE to acidification between our study and previous studies may largely be attributed to different ranges of soil $\mathrm{pH}$. The $\mathrm{pH}$ range (from 6.9 to 5.9) in our study was much higher than the $\mathrm{pH}$ threshold (5.5) proposed by Jones et al. (2019) at which detrimental effects 
of exchangeable $\mathrm{Al}$ occurred. This suggests that the effect of changing $\mathrm{pH}$ on CUE can vary significantly depending on the initial soil $\mathrm{pH}$ and ecosystem type. Although our study proved a stronger regulation by stoichiometric adaption than metal toxicity in soil acidification, whether the negative effects of growing microbial stress under high atmospheric $\mathrm{N}$ and $\mathrm{S}$ deposition, especially when soil $\mathrm{pH}$ falls below 5.5, would exceed the capacity of microbial adaption to element limitation is still an open question. Consequently, more long-term observations are needed for a better understanding of microbial adaption to soil acidification.

\section{Conclusions}

Our study demonstrated that soil acidification resulted in conversion from microbial $\mathrm{N}$ limitation to $\mathrm{C}$ limitation, as suggested by a decrease in the C:N imbalance between microbial biomass and their resources in calcareous grassland soils. To cope with the increasing $\mathrm{C} v s . \mathrm{N}$ limitation, the microbial community tended to alter enzyme production and increase CUE but decrease NUE under soil acidification. Our results revealed that changing the nutrient-use efficiencies of the microbial communities under soil acidification was not only a microbial adjustment to increasing $\mathrm{N}$ availability but, more importantly, an adaption to an altered community structure. Our results also highlighted the importance of stoichiometric controls on microbial elemental use efficiency relative to the detrimental effects of metal stress. However, long-term observation is needed because a continuous drop in $\mathrm{pH}$ may aggravate the adverse effects of metal stress on microbial nutrient acquisition and utilization processes. These findings may improve the understanding of soil microbe-driven nutrient cycling and help better simulation and projection of future dynamics of terrestrial biosphere under climate change.

\footnotetext{
Abbreviations

DOC: Dissolved organic carbon; TDN: Total dissolved nitrogen; MBC: Microbial biomass carbon; MBN: Microbial biomass nitrogen; BG: $\beta$ glucosidase; NAG: $\beta$-N-acetyl-glucosaminidase; LAP: Leucine aminopeptidase; TER: Threshold element ratio; CUE: Carbon-use efficiency; NUE: Nitrogen-use efficiency; F:B: The ratio of fungi to bacteria; sat:mono: The ratio of saturatedto-monounsaturated PLFAs; cy:pre: The ratio of cyclopropyl FA-to-monoenoic precursor; SMA: Standardized principal axis; PCA: Principal component analysis; SEM: Structural equation model
}

\section{Supplementary Information}

The online version contains supplementary material available at https://doi. org/10.1186/s13717-021-00309-1.

Additional file 1 Appendix 1 - Additional methods (Detailed priori hypothetical pathways and a priori structural equation model); Appendix 2- Additional results (Soil biochemical characteristics, SMA regression for enzymes and correlation between variables and element-use efficiency);
Appendix 3- Reliability test for estimated CUE (Soil respiration and its relationship with estimated CUE).

\section{Acknowledgements}

The authors thank the anonymous reviewers for their insightful comments on an earlier version of this MS. We thank Erguna Forest-Steppe Ecotone Research Station for logistic supports.

\section{Authors' contributions}

Y.J. designed the study. T.L. and H.L. set up the field experiment and applied fertilizer every year. T.L. and Z.W. performed soil sampling and completed laboratory analyses. T.L. and Y.M. performed statistical analyses and graphs. R.W., J.C. and R.F.T. contributed to the interpretation and discussion of the results. T.L. prepared the manuscript with suggestions from all the coauthors. All authors read and approved the final manuscript.

\section{Funding}

This work was financially supported by the National Natural Science Foundation of China (31870441, 32071563, and 31800398) and the Strategic Priority Research Program of the Chinese Academy of Sciences (XDA23080400), and the Key State Research \& Development Program of China (2016YFC0500601).

Availability of data and materials

The datasets generated during and/or analyzed during the current study are available from the corresponding author on reasonable request.

\section{Declarations}

Ethics approval and consent to participate

Not applicable.

Consent for publication

Not applicable.

\section{Competing interests}

The authors have no conflicts of interest to declare that are relevant to the content of this article.

\section{Author details}

${ }^{1}$ Erguna Forest-Steppe Ecotone Ecosystem Research Station, Institute of Applied Ecology, Chinese Academy of Sciences, Shenyang 110016, China. ${ }^{2}$ University of Chinese Academy of Sciences, Beijing 100049, China.

${ }^{3}$ Department of Agronomy, Purdue University, West Lafayette, IN 47907, USA.

Received: 1 April 2021 Accepted: 5 May 2021

Published online: 17 May 2021

\section{References}

Åkerblom S, Bååth E, Bringmark L, Bringmark E (2007) Experimentally induced effects of heavy metal on microbial activity and community structure of forest mor layers. Biol Fertil Soils 44(1):79-91. https://doi.org/10.1007/s00374007-0181-2

Allison SD (2006) Soil minerals and humic acids alter enzyme stability: implications for ecosystem processes. Biogeochemistry 81(3):361-373. https:// doi.org/10.1007/s10533-006-9046-2

Allison SD, Vitousek PM (2005) Responses of extracellular enzymes to simple and complex nutrient inputs. Soil Biol Biochem 37(5):937-944. https://doi.org/10.1 016/j.soilbio.2004.09.014

Auger C, Han S, Appanna VP, Thomas SC, Ulibarri G, Appanna VD (2013) Metabolic reengineering invoked by microbial systems to decontaminate aluminum: implications for bioremediation technologies. Biotechnol Adv 31(2):266-273. https://doi.org/10.1016/j.biotechadv.2012.11.008

Averill C, Waring B (2018) Nitrogen limitation of decomposition and decay: How can it occur? Glob Change Biol 24(4):1417-1427. https://doi.org/10.1111/ gcb.13980

Bååth E, Anderson TH (2003) Comparison of soil fungal/bacterial ratios in a pH gradient using physiological and PLFA-based techniques. Soil Biol Biochem 35:955-963. https://doi.org/10.1016/s0038-0717(03)00154-8 
Bardgett RD, Bowman WD, Kaufmann R, Schmidt SK (2005) A temporal approach to linking aboveground and belowground ecology. Trends Ecol Evol 20(11): 634-641. https://doi.org/10.1016/j.tree.2005.08.005

Bellion M, Courbot M, Jacob C, Blaudez D, Chalot M (2006) Extracellular and cellular mechanisms sustaining metal tolerance in ectomycorrhizal fungi. FEMS Microbiol Lett 254(2):173-181. https://doi.org/10.1111/j.1574-6968.2005. 00044.x

Bole JB (1986) Amelioration of a calcareous solonetzic soil by irrigation, deep ripping, and acidification with elemental sulfur. Can J Soil Sci 66(2):347-356. https://doi.org/10.4141/cjss86-035

Bossio DA, Scow KM (1998) Impacts of carbon and flooding on soil microbial communities: phospholipid fatty acid profiles and substrate utilization patterns. Microb Ecol 35(3):265-278. https://doi.org/10.1007/s002489900082

Bowman WD, Cleveland CC, Halada L, Hreško J, Baron JS (2008) Negative impact of nitrogen deposition on soil buffering capacity. Nat Geosci 1(11):767-770. https://doi.org/10.1038/ngeo339

Brookes PC, Landman A, Pruden G, Jenkinson DS (1985) Chloroform fumigation and the release of soil nitrogen: A rapid direct extraction method to measure microbial biomass nitrogen in soil. Soil Biol Biochem 17:837-842. https://doi. org/10.1016/0038-0717(85)90144-0

Chen D, Lan Z, Bai X, Grace JB, Bai Y, van der Heijden M (2013) Evidence that acidification-induced declines in plant diversity and productivity are mediated by changes in below-ground communities and soil properties in a semi-arid steppe. J Ecol 101(5):1322-1334. https://doi.org/10.1111/1365-274 5.12119

Cui J, Zhou J, Peng Y, He Y, Yang H, Mao J (2014) Atmospheric wet deposition of nitrogen and sulfur to a typical red soil agroecosystem in Southeast China during the ten-year monsoon seasons (2003-2012). Atmos Environ 82:121129. https://doi.org/10.1016/j.atmosenv.2013.10.023

Cui Y, Fang L, Guo X, Wang X, Zhang Y, Li P, Zhang X (2018) Ecoenzymatic stoichiometry and microbial nutrient limitation in rhizosphere soil in the arid area of the northern Loess Plateau, China. Soil Biol Biochem 116:11-21. https://doi.org/10.1016/j.soilbio.2017.09.025

Dilly O, Nannipieri P (2001) Response of ATP content, respiration rate and enzyme activities in an arable and a forest soil to nutrient additions. Biol Fertil Soils 34:64-72. https://doi.org/10.1007/s003740100375

Domeignoz-Horta LA, Pold G, Liu XA, Frey SD, Melillo JM, DeAngelis KM (2020) Microbial diversity drives carbon use efficiency in a model soil. Nat Commun 11(1):3684. https://doi.org/10.1038/s41467-020-17502-Z

Feng X, Wang R, Yu Q, Cao Y, Zhang Y, Yang L, Dijkstra FA, Jiang Y (2019) Decoupling of plant and soil metal nutrients as affected by nitrogen addition in a meadow steppe. Plant Soil 443(1-2):337-351. https://doi.org/10.1007/ S11104-019-04217-4

Frost PC, Benstead JP, Cross WF, Hillebrand $\mathrm{H}$, Larson JH, Xenopoulos MA, Yoshida T (2006) Threshold elemental ratios of carbon and phosphorus in aquatic consumers. Ecol Lett 9(7):774-779. https://doi.org/10.1111/j.1461-024 8.2006.00919.x

Frostegård A, Bååth E (1996) The use of phospholipid fatty acid analysis to estimate bacterial and fungal biomass in soil. Biol Fertil Soils 22:59-65. https://doi.org/10.1007/bf00384433

Garcia-Sanchez M, Garcia-Romera I, Cajthaml T, Tlustos P, Szakova J (2015) Changes in soil microbial community functionality and structure in a metalpolluted site: The effect of digestate and fly ash applications. J Environ Manage 162:63-73. https://doi.org/10.1016/j.jenvman.2015.07.042

Ge B, Wang Z, Xu X, Wu J, Yu X, Li J (2014) Wet deposition of acidifying substances in different regions of China and the rest of East Asia: modeling with updated NAQPMS. Environ Pollut 187:10-21. https://doi.org/10.1016/j. envpol.2013.12.014

Geyer KM, Dijkstra P, Sinsabaugh R, Frey SD (2019) Clarifying the interpretation of carbon use efficiency in soil through methods comparison. Soil Biol Biochem 128:79-88. https://doi.org/10.1016/j.soilbio.2018.09.036

Guo K, Zhao Y, Liu Y, Chen J, Wu Q, Ruan Y, Li S, Shi J, Zhao L, Sun X, Liang C, Xu Q, Qin H (2020) Pyrolysis temperature of biochar affects ecoenzymatic stoichiometry and microbial nutrient-use efficiency in a bamboo forest soil. Geoderma 363:114162. https://doi.org/10.1016/j.geoderma.2019.114162

Hofmockel KS, Fierer N, Colman BP, Jackson RB (2010) Amino acid abundance and proteolytic potential in North American soils. Oecologia 163(4):10691078. https://doi.org/10.1007/s00442-010-1601-9

Joergensen RG (1996) The fumigation-extraction method to estimate soil microbial biomass: Calibration of the KEC value. Soil Biol Biochem 28:25-31. https://doi.org/10.1016/0038-0717(95)00102-6
Jones DL, Cooledge EC, Hoyle FC, Griffiths Rl, Murphy DV (2019) pH and exchangeable aluminum are major regulators of microbial energy flow and carbon use efficiency in soil microbial communities. Soil Biol Biochem 138: 107584. https://doi.org/10.1016/j.soilbio.2019.107584

Kaiser C, Franklin O, Dieckmann U, Richter A (2014) Microbial community dynamics alleviate stoichiometric constraints during litter decay. Ecol Lett 17(6):680-690. https://doi.org/10.1111/ele.12269

Kaur A, Chaudhary A, Kaur A, Choudhary R, Kaushik R (2005) Phospholipid fatty acid - A bioindicator of environment monitoring and assessment in soil ecosystem. Curr Sci 89:1103-1112

Keiblinger KM, Hall EK, Wanek W, Szukics U, Hammerle I, Ellersdorfer G, Bock S, Strauss J, Sterflinger K, Richter A, Zechmeister-Boltenstern S (2010) The effect of resource quantity and resource stoichiometry on microbial carbon-useefficiency. FEMS Microbiol Lett 73:430-440. https://doi.org/10.1111/j.1574$6941.2010 .00912 x$

Kemmitt SJ, Wright D, Jones DL (2005) Soil acidification used as a management strategy to reduce nitrate losses from agricultural land. Soil Biol Biochem 37(5):867-875. https://doi.org/10.1016/j.soilbio.2004.10.001

Kunito T, Isomura I, Sumi H, Park H-D, Toda H, Otsuka S, Nagaoka K, Saeki K, Senoo K (2016) Aluminum and acidity suppress microbial activity and biomass in acidic forest soils. Soil Biol Biochem 97:23-30. https://doi.org/10.1 016/j.soilbio.2016.02.019

László S, Tünde P, Tamás E, Zoltán V, Andrea F, Ágnes G, Zsolt K, László K, István P (2001) Autolysis and aging of Penicillium chrysogenum cultures under carbon starvation: Chitinase production and antifungal effect of allosamidin. J Gen Appl Microbiol 47(4):201-211. https://doi.org/10.2323/jgam.47.201

Li Z, Zeng Z, Tian D, Wang J, Fu Z, Wang B, Tang Z, Chen W, Chen HYH, Wang C, Yi C, Niu S (2020) The stoichiometry of soil microbial biomass determines metabolic quotient of nitrogen mineralization. Environ Res Lett 15(3):034005. https://doi.org/10.1088/1748-9326/ab6a26

Los DA, Murata N (2004) Membrane fluidity and its roles in the perception of environmental signals. Biochim Biophys Acta-Biomembr 1666(1-2):142-157. https://doi.org/10.1016/j.bbamem.2004.08.002

Lu X, Mao Q, Gilliam FS, Luo Y, Mo J (2014) Nitrogen deposition contributes to soil acidification in tropical ecosystems. Glob Change Biol 20(12):3790-3801. https://doi.org/10.1111/gcb.12665

Malik AA, Thomson BC, Whiteley AS, Bailey M, Griffiths RI (2017) Bacterial physiological adaptations to contrasting edaphic conditions identified using landscape scale metagenomics. mBio 8(4):e0079917. https://doi.org/10.1128/ mBio.00799-17

Manzoni S, Trofymow JA, Jackson RB, Porporato A (2010) Stoichiometric controls on carbon, nitrogen, and phosphorus dynamics in decomposing litter. Ecol Monogr 80(1):89-106. https://doi.org/10.1890/09-0179.1

Meng C, Tian D, Zeng H, Li Z, Yi C, Niu S (2019) Global soil acidification impacts on belowground processes. Environ Res Lett 14(7):074003. https://doi.org/1 $0.1088 / 1748-9326 / a b 239 c$

Mooshammer M, Wanek W, Hammerle I, Fuchslueger L, Hofhansl F, Knoltsch A, Schnecker J, Takriti M, Watzka M, Wild B, Keiblinger KM, ZechmeisterBoltenstern S, Richter A (2014b) Adjustment of microbial nitrogen use efficiency to carbon:nitrogen imbalances regulates soil nitrogen cycling. Nat Commun 5(1):3694. https://doi.org/10.1038/ncomms4694

Mooshammer M, Wanek W, Zechmeister-Boltenstern S, Richter A (2014a) Stoichiometric imbalances between terrestrial decomposer communities and their resources: mechanisms and implications of microbial adaptations to their resources. Front Microbiol 5:22. https://doi.org/10.3389/fmicb.2014.00022

Mori T (2020) Does ecoenzymatic stoichiometry really determine microbial nutrient limitations? Soil Biol Biochem 146:107816. https://doi.org/10.1016/j. soilbio.2020.107816

Nannipieri P, Trasar-Cepeda C, Dick RP (2018) Soil enzyme activity: a brief history and biochemistry as a basis for appropriate interpretations and meta-analysis. Biol Fertil Soils 54(1):11-19. https://doi.org/10.1007/s00374-017-1245-6

Olsson PA, Bååth E, Jakobsen I, Söderström B (1995) The use of phospholipid and neutral lipid fatty acids to estimate biomass of arbuscular mycorrhizal fungi in soil. Mycol Res 99:623-629. https://doi.org/10.1016/s0953-7562(09)80723-5

Owen KM, Marrs RH, Snow CSR, Evans CE (1999) Soil acidification-the use of sulphur and acidic plant materials to acidify arable soils for the recreation of heathland and acidic grassland at Minsmere, UK. Biol Conserv 87:105-121. https://doi.org/10.1016/S0006-3207(98)00027-5

Poschenrieder C, Gunse B, Corrales I, Barcelo J (2008) A glance into aluminum toxicity and resistance in plants. Sci Total Environ 400(1-3):356-368. https:// doi.org/10.1016/j.scitotenv.2008.06.003 
Puissant J, Jones B, Goodall T, Mang D, Blaud A, Gweon HS, Malik A, Jones DL, Clark IM, Hirsch PR, Griffiths R (2019) The pH optimum of soil exoenzymes adapt to long term changes in soil pH. Soil Biol Biochem 138:107601. https:// doi.org/10.1016/.j.soilbio.2019.107601

Riggs CE, Hobbie SE (2016) Mechanisms driving the soil organic matter decomposition response to nitrogen enrichment in grassland soils. Soil Biol Biochem 99:54-65. https://doi.org/10.1016/j.soilbio.2016.04.023

Robertson GP, Coleman DC, Sollins P, Bledsoe CS (1999) Standard soil methods for long-term ecological research. Oxford University Press, New York

Roels JA (1980) Application of macroscopic principles to microbial metabolism. Biotechnol Bioeng 22(12):2457-2514. https://doi.org/10.1002/bit.260221202

Rousk J, Baath E, Brookes PC, Lauber CL, Lozupone C, Caporaso JG, Knight R, Fierer N (2010a) Soil bacterial and fungal communities across a pH gradient in an arable soil. ISME J 4(10):1340-1351. https://doi.org/10.1038/ismej.2010. 58

Rousk J, Brookes PC, Baath E (2009) Contrasting soil pH effects on fungal and bacterial growth suggest functional redundancy in carbon mineralization. Appl Environ Microbiol 75(6):1589-1596. https://doi.org/10.1128/AEM.0277508

Rousk J, Brookes PC, Bååth E (2010b) The microbial PLFA composition as affected by $\mathrm{pH}$ in an arable soil. Soil Biol Biochem 42(3):516-520. https://doi.org/10.1 016/j.soilbio.2009.11.026

Schimel JP, Weintraub MN (2003) The implications of exoenzyme activity on microbial carbon and nitrogen limitation in soil: a theoretical model. Soil Biol Biochem 35:549-563. https://doi.org/10.1016/S0038-0717(03)00015-4

Schleuss P-M, Widdig M, Heintz-Buschart A, Guhr A, Martin S, Kirkman K, Spohn M (2019) Stoichiometric controls of soil carbon and nitrogen cycling after long-term nitrogen and phosphorus addition in a mesic grassland in South Africa. Soil Biol Biochem 135:294-303. https://doi.org/10.1016/j.soilbio.2019. 05.018

Schrijver A, Frenne P, Staelens J, Verstraeten G, Muys B, Vesterdal L, Wuyts K, Nevel L, Schelfhout S, Neve S, Verheyen K (2012) Tree species traits cause divergence in soil acidification during four decades of postagricultural forest development. Glob Change Biol 18(3):1127-1140. https://doi.org/10.1111/j.13 65-2486.2011.02572.x

Siles JA, Cajthaml T, Hernandez P, Perez-Mendoza D, Garcia-Romera I, Sampedro I (2015) Shifts in soil chemical properties and bacterial communities responding to biotransformed dry olive residue used as organic amendment. Microb Ecol 70(1):231-243. https://doi.org/10.1007/s00248-014-0552-9

Silver S, Nucifora G, Chu L, Misra TK (1989) Bacterial resistance ATPases: primary pumps for exporting toxic cations and anions. Trends Biochem Sci 14:76-80. https://doi.org/10.1016/0968-0004(89)90048-0

Sinsabaugh RL, Hill BH, Follstad Shah JJ (2009) Ecoenzymatic stoichiometry of microbial organic nutrient acquisition in soil and sediment. Nature 462(7274): 795-798. https://doi.org/10.1038/nature08632

Sinsabaugh RL, Klug MJ, Collins HP, Yeager PE, Petersen SO (1999) Characterizing Soil Microbial Communities. In: Robertson GP, Coleman DC, Sollins P, Bledsoe CS (eds) Standard soil methods for long-term ecological research, Part IV Soil Organisms, vol 2. Oxford University Press, Madison, pp 318-348

Sinsabaugh RL, Manzoni S, Moorhead DL, Richter A (2013) Carbon use efficiency of microbial communities: stoichiometry, methodology and modelling. Ecol Lett 16(7):930-939. https://doi.org/10.1111/ele.12113

Sinsabaugh RL, Turner BL, Talbot JM, Waring BG, Powers JS, Kuske CR, Moorhead DL, Shah JJF (2016) Stoichiometry of microbial carbon use efficiency in soils. Ecol Monogr 86(2):172-189. https://doi.org/10.1890/15-2110.1

Spohn M (2016) Element cycling as driven by stoichiometric homeostasis of soi microorganisms. Basic Appl Ecol 17(6):471-478. https://doi.org/10.1016/j.baa e.2016.05.003

Spohn M, Pötsch EM, Eichorst SA, Woebken D, Wanek W, Richter A (2016) Soil microbial carbon use efficiency and biomass turnover in a long-term fertilization experiment in a temperate grassland. Soil Biol Biochem 97:168175. https://doi.org/10.1016/j.soilbio.2016.03.008

Sterner RW, Elser JJ (2002) Ecological stoichiometry: the biology of elements from molecules to the biosphere. Princeton University Press, New Jersey

Strickland MS, Rousk J (2010) Considering fungal:bacterial dominance in soils Methods, controls, and ecosystem implications. Soil Biol Biochem 42(9):13851395. https://doi.org/10.1016/j.soilbio.2010.05.007

Tabatabai MA (1994) Soil enzymes. In: Weaver RW, Angle JS, Bottomley PS (eds) Methods of soil analysis, part 2 Microbiological and Biochemical Properties. Soil Science Society of America, Madison, pp 775-833
Tapia-Torres Y, Elser JJ, Souza V, García-Oliva F (2015) Ecoenzymatic stoichiometry at the extremes: How microbes cope in an ultra-oligotrophic desert soil. Soil Biol Biochem 87:34-42. https://doi.org/10.1016/j.soilbio.2015.04.007

Treseder KK (2008) Nitrogen additions and microbial biomass: a meta-analysis of ecosystem studies. Ecol Lett 11(10):1111-1120. https://doi.org/10.1111/j.14610248.2008.01230.x

Van Den Berg LJL, Dorland E, Vergeer P, Hart MAC, Bobbink R, Roelofs JGM (2005) Decline of acid-sensitive plant species in heathland can be attributed to ammonium toxicity in combination with low pH. New Phytol 166(2):551564. https://doi.org/10.1111/j.1469-8137.2005.01338.x

Vance ED, Brookes PC, Jenkinson DS (1987) An extraction method for measuring soil microbial biomass C. Soil Biol Biochem 19:703-707. https://doi.org/10.101 6/0038-0717(87)90052-6

Vanguelova El, Nortcliff S, Moffat AJ, Kennedy F (2007) Short-term effects of manipulated increase in acid deposition on soil, soil solution chemistry and fine roots in Scots pine (Pinus sylvestris) stand on a podzol. Plant Soil 294(12):41-54. https://doi.org/10.1007/s11104-007-9225-5

Wang AS, Angle JS, Chaney RL, Delorme TA, Mclntosh M (2006) Changes in soil biological activities under reduced soil $\mathrm{pH}$ during Thlaspi caerulescens phytoextraction. Soil Biol Biochem 38(6):1451-1461. https://doi.org/10.1016/j. soilbio.2005.11.001

Wang R, Dorodnikov M, Yang S, Zhang Y, Filley TR, Turco RF, Zhang Y, Xu Z, Li H, Jiang $Y$ (2015) Responses of enzymatic activities within soil aggregates to 9year nitrogen and water addition in a semi-arid grassland. Soil Biol Biochem 81:159-167. https://doi.org/10.1016/j.soilbio.2014.11.015

Waring BG, Weintraub SR, Sinsabaugh RL (2013) Ecoenzymatic stoichiometry of microbial nutrient acquisition in tropical soils. Biogeochemistry 117(1):101113. https://doi.org/10.1007/s10533-013-9849-x

Warton DI, Duursma RA, Falster DS, Taskinen S (2012) smatr 3 - an R package for estimation and inference about allometric lines. Methods Ecol Evol 3(2):257259. https://doi.org/10.1111/j.2041-210X.2011.00153.x

Wild B, Schnecker J, Knoltsch A, Takriti M, Mooshammer M, Gentsch N, Mikutta R, Alves RJ, Gittel A, Lashchinskiy N, Richter A (2015) Microbial nitrogen dynamics in organic and mineral soil horizons along a latitudinal transect in western Siberia. Glob Biogeochem Cycle 29(5):567-582. https://doi.org/10.1 002/2015GB005084

Xiao H, Wang B, Lu S, Chen D, Wu Y, Zhu Y, Hu S, Bai Y (2020) Soil acidification reduces the effects of short-term nutrient enrichment on plant and soil biota and their interactions in grasslands. Glob Change Biol 26(8):4626-4637. https://doi.org/10.1111/gcb.15167

Yang Y, Ji C, Ma W, Wang S, Wang S, Han W, Mohammat A, Robinson D, Smith P (2012) Significant soil acidification across northern China's grasslands during 1980s-2000s. Glob Change Biol 18(7):2292-2300. https://doi.org/10.1111/j.13 65-2486.2012.02694.x

Yu H, He N, Wang Q, Zhu J, Gao Y, Zhang Y, Jia Y, Yu G (2017) Development of atmospheric acid deposition in China from the 1990s to the 2010s. Environ Pollut 231(Pt 1):182-190. https://doi.org/10.1016/j.envpol.2017.08.014

Yuan X, Niu D, Gherardi LA, Liu Y, Wang Y, Elser JJ, Fu H (2019) Linkages of stoichiometric imbalances to soil microbial respiration with increasing nitrogen addition: Evidence from a long-term grassland experiment. Soil Biol Biochem 138:107580. https://doi.org/10.1016/j.soilbio.2019.107580

Zechmeister-Boltenstern S, Keiblinger KM, Mooshammer M, Peñuelas J, Richter A, Sardans J, Wanek W (2015) The application of ecological stoichiometry to plant-microbial-soil organic matter transformations. Ecol Monogr 85(2):133155. https://doi.org/10.1890/14-0777.1

Zhang W, Xu Y, Gao D, Wang X, Liu W, Deng J, Han X, Yang G, Feng Y, Ren G (2019) Ecoenzymatic stoichiometry and nutrient dynamics along a revegetation chronosequence in the soils of abandoned land and Robinia pseudoacacia plantation on the Loess Plateau, China. Soil Biol Biochem 134: 1-14. https://doi.org/10.1016/j.soilbio.2019.03.017

\section{Publisher's Note}

Springer Nature remains neutral with regard to jurisdictional claims in published maps and institutional affiliations. 